\title{
Chemical dissociation of human awareness: focus on non-competitive NMDA receptor antagonists
}

\author{
Edward F. Domino \\ Department of Pharmacology, University of Michigan, Ann Arbor, MI 48109-0626, USA
}

Since the mid-1950s the pharmaceutical industry has developed a number of chemicals, including phencyclidine, ketamine and related arylcyclohexylamines (PCE and TCP), dizocilpine (MK-801), $N$-allylnormetazocine [NANM, ( \pm SKF-10,047], etoxadrol, dioxadrol and its enantiomers dexoxadrol and levoxadrol, which produce a constellation of unusual behavioral effects in animals and man. The compounds best studied in humans are phencyclidine and ketamine. They produce a remarkable dose-dependent dissociation of awareness. All of these substances are now known to be non-competitive antagonists of NMDA receptors of glutamic acid. They act in the NMDA receptor ion channel. One can conclude, on the basis of the effects observed with these agents, that glutamic acid and related excitatory amino acids are extremely important in the maintenance of human awareness.

Key words: NMDA receptor antagonists; awareness; dissociation

\section{Introduction}

There are many chemical substances that, when taken by humans, increase, decrease or dramatically alter awareness. Consciousness has many components including awareness of the external environment, one's body image, concept of self and identity. Alertness can easily be distinguished from natural sleep, dreaming, stupor, general anesthesia and coma. Many chemicals and drugs alter consciousness, affecting subjective awareness and experience. They alter brain responses to sensory inputs from the external and internal environment. Almost all chemicals or drugs which act on the brain alter levels of awareness. These include drugs of abuse as well as socially approved or tolerated substances such as ethyl alcohol, caffeine, nicotine and medications such as narcotics and psychotropics. Alteration of awareness by chemical means has been practiced by every human culture since man's earliest recorded beginnings. The concept of the dose of the substance taken is crucial. For example, depending on dose, $d$-amphetamine may increase awareness or alter it dramatically, leading to frank psychosis.

An interesting means of chemical dissociation of awareness is through the use of substances which alter the function of the NMDA receptor of the excitatory amino acid neurotransmitter, glutamic acid. There are many substances which either increase or decrease the functional state of this glutamatergic synapse and, hence, dramatically alter awareness. The present communication summarizes our current knowledge of the different chemicals which alter NMDA receptor function by blocking its ion channel and thus altering human awareness. The substances selected for review have all been given to humans, but some have been inadequately studied in man.

\section{Phencyclidine}

Phencyclidine was first given to humans in the late 1950s. It was initially studied as an intravenous anesthetic (Greifenstein et al., 1958; Johnstone, Evans and Baigel, 1959), and later as a chemical model of sensory deprivation (Meyer, Greifenstein and DeVault, 1959) and schizophrenia (Luby et al., 1959, 1962; Cohen et al., 1959) well before its primary mechanism of action was determined to be that of a non-competitive NMDA receptor antagonist.

The history of phencyclidine and related arylcyclohexylamines was described by a number of the early investigators. It has been documented from the point of view of a medicinal chemist (Maddox, 1981), neuropharmacologist (Chen, 1981; McCarthy, 1981) and a psychiatrist (Luby, 1981). Domino and Luby (1981) compared some of the symptoms of schizophrenia with those induced by phencyclidine, sensory isolation, sleep deprivation and LSD-25. Their summary table is reproduced as Table 1 . It is very clear that none of the models of schizophrenia mimic precisely the symptoms of the natural disease, but phencyclidine seems to be a 
Table 1 Comparison of various symptoms of schizophrenia with those induced by phencyclidine, sensory isolation, sleep deprivation and LSD-25

\begin{tabular}{|c|c|c|c|c|c|}
\hline Symptom & $\begin{array}{c}\text { Acute } \\
\text { schizophrenia }\end{array}$ & Phencyclidine & $\begin{array}{l}\text { Sensory } \\
\text { isolation }\end{array}$ & $\begin{array}{c}\text { Sleep } \\
\text { deprivation }\end{array}$ & LSD-25 \\
\hline Loosening of association & ++++ & ++ & + & + . & ++ \\
\hline Overinclusive thoughts & $t+t$ & ++ & + & + & ++ \\
\hline Concreteness & ++ & ++++ & + & ++ & + \\
\hline Ambivalence & +++ & ++ & + & + & +++ \\
\hline Autistic dreamy states & +++ & +++ & $+t+$ & ++++ & +++ \\
\hline Affect disorder & $++t+$ & ++ & + & ++ & $+t+$ \\
\hline Attention disorder & $+t+$ & +++ & + & ++++ & +++ \\
\hline Depersonalization & +++ & ++++ & ++ & +++ & +++ \\
\hline Feelings of influence & +++ & + & + & + & + \\
\hline Delusional thinking & $+t+t$ & + & + & ++ & ++ \\
\hline Visual hallucinations & & + & + & ++++ & ++++ \\
\hline Auditory hallucinations & +++ & & + & + & \\
\hline Withdrawal & +++ & + & & & + \\
\hline EEG changes & only induced & $+t+$ & + & ++++ & ++ \\
\hline Chlorpromazine response & +++ & + & + & + & +++ \\
\hline Intensified by amphetamine & $++t$ & + & + & + & +++ \\
\hline Catatonia & + & + & + & + & + \\
\hline Clouding delirium & + & $++t$ & + & +++ & ++ \\
\hline Response to isolation & ++ & ++ & & + & ++ \\
\hline
\end{tabular}

From Domino and Luby, 1981

better model than the others. Luby et al. (1959) and Cohen et al. (1959) gave the drug as an i.v. infusion in a dose of $0.1 \mathrm{mg} / \mathrm{kg}$ in $150 \mathrm{ml}$ in $5 \%$ glucose. Normal volunteers showed five major psychological changes including:

1. most commonly loss of ego boundaries;

2. intellectual impairment;

3. induction of affectively charged personal experiences;

4. a pervasive sense of isolation;

5. fluctuations in the psychological environment with feelings of being in past settings with a lack of time boundedness.

A few drug-free schizophrenic patients given phencyclidine generally became more assertive, hostile and unmanageable, with behavioral changes lasting for approximately 1 month. This was in contrast to the shortlasting effects in the normal volunteers. One catatonic patient became worse directly after receiving phencyclidine, but 4 days later emerged from his stuporous state. He remembered his strange experience with phencyclidine and maintained a behavioral improvement for $\sim 1.5$ months.

Two other phencyclidine derivatives, $N$-ethyl-1phenylcyclohexamine (CI-400, PCE) and 1- [1-(2-thienyl) cyclohexyl] piperidine (CI-421, TCP), were also tested in humans as i.v. anesthetics. They were found to produce similar qualitative emergence phenomena that were quantitatively a little different. Phencyclidine and TCP especially produced typical, similar EEG changes with sharp waves, particularly in young patients. All three agents were given in doses of
$0.25-0.35 \mathrm{mg} / \mathrm{kg}$ i.v. (Lear et al., 1959; Scholler, Thies and Wiemers, 1960).

More recently, Javitt and Zukin (1991) emphasized that a number of positive and negative symptoms of schizophrenia can be induced in normal volunteers or drug abusers with phencyclidine. Carlsson and Carlsson (1990) have observed in animals interactions between glutamatergic and monoaminergic systems in the brain that have implications for schizophrenia.

Fauman and Fauman (1981) and Burns and Lerner (1981) reviewed in detail the drug abuse aspects and pharmacology of phencyclidine in man. Table 2 lists the dose-effect relationships of phencyclidine in normal or drug abuse subjects as reported by Burns and Lerner (1981). It should be noted that in many respects phencyclidine ingestion or infusion in humans is a better model of an organic brain syndrome inducing delirium and, in sufficient dose, loss of memory and consciousness. This has not been emphasized in the current literature.

\section{Ketamine}

Ketamine is an arylcyclohexylamine derivative of phencyclidine. It is also a non-competitive NMDA antagonist. Lodge and his colleagues (1983) were the first to show that ketamine, phencyclidine, related arylcyclohexylamines and congeners were antagonists of excitatory amino acids like aspartate and glutamate. The early history of the development of ketamine as an anesthetic agent is documented by McCarthy (1981). Corssen (1990) and Dundee (1990a,b) have reviewed the 
Table 2 Dose-related effects of phencyclidine in normal subjects

\begin{tabular}{rrrrrrrrrr} 
& Total dose by i.v. infusion: & $1 \mathrm{mg}$ & $2 \mathrm{mg}$ & $7 \mathrm{mg}$ & $7-10 \mathrm{mg}$ & $14 \mathrm{mg}$ & $17.5 \mathrm{mg}$ & $35 \mathrm{mg}$ & $70 \mathrm{mg}$ \\
\hline $\mathrm{mg} / \mathrm{kg}:$ & 0.014 & 0.03 & 0.10 & & 0.20 & 0.25 & 0.50 & 1.0 \\
\hline
\end{tabular}

Acute effects:

Subjective effects

Nystagmus

Gait ataxia

Increased blood pressure

Confusional state

Theta slowing (EEG)

Anesthesia-analgesia (loss of consciousness, no response to painful or auditory stimuli)

Amnesia

Purposeless movements (state of agitation)

Muscle rigidity and extensor posturing (severe rigidity and catatonia)

Seizure activity

Respiratory depression

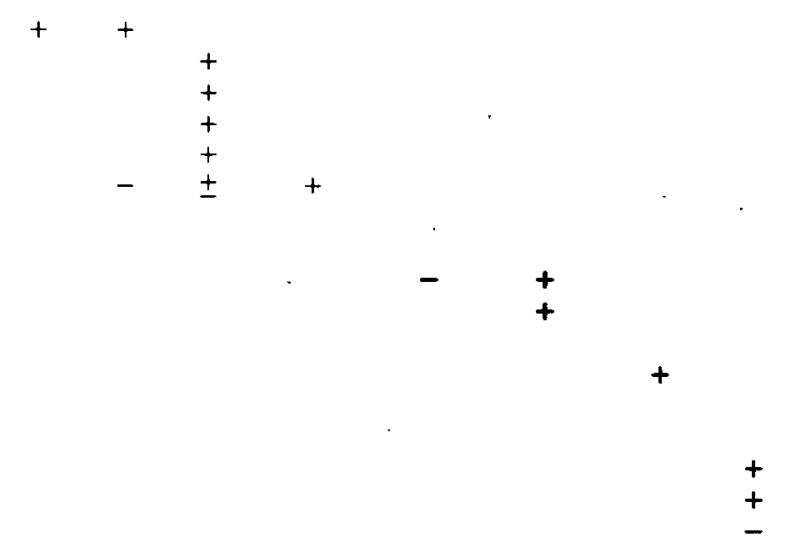

From Burns and Lerner, 1981

historical introduction of ketamine into human anesthesia and the term dissociative anesthesia (Domino, Chodoff and Corssen, 1965; Corssen and Domino, 1966). It was clear to all of the anesthesiologists and clinical pharmacologists who used ketamine that there was a need to tame the ketamine 'tiger'. Albin, Bunegin and Garcia (1990) have detailed the post-anesthetic emergence reactions to ketamine involving $>12283$ different procedures in 10861 patients. Their findings are summarized in Table 3.

Øye et al. (1991) studied the $S$ - and $R-(0.5 \mathrm{mg} / \mathrm{kg}$ i.v. $)$ forms of ketamine in normal volunteers. The $S$-form is more potent and selective for NMDA receptor blockade while the $R$-form has more sigma receptor affinity. Their figure and legend of the 'effects of ketamine on the gates of perception' is reproduced herein as Fig. 1 and is especially pertinent.

Table 3 Incidence rates for select adverse reactions in 12183 procedures (10861 patients) participating in 88 studies with CI-581 (with and without those considered non-drug-attributable)

\begin{tabular}{|c|c|c|c|c|}
\hline \multirow{3}{*}{ Adverse reaction } & \multicolumn{4}{|c|}{ Incidence rates } \\
\hline & \multicolumn{2}{|c|}{$\begin{array}{l}\text { Including those } \\
\text { considered non- } \\
\text { drug-attributable }\end{array}$} & \multicolumn{2}{|c|}{$\begin{array}{l}\text { Excluding those } \\
\text { considered non- } \\
\text { drug-attributable }\end{array}$} \\
\hline & Number & Percent & Number & Percent \\
\hline Dreams (pleasant) & 837 & 6.81 & 679 & 5.53 \\
\hline Dreams (unpleasant) & 207 & 1.69 & 199 & 1.62 \\
\hline Hallucinations & 210 & 1.71 & 152 & 1.24 \\
\hline Psychic abnormality & 74 & 0.60 & 62 & 0.50 \\
\hline \multirow{3}{*}{$\begin{array}{l}\text { Confusion } w / \text { wo } \\
\text { vocalization } \\
\text { Moaning, groaning or } \\
\text { crying }\end{array}$} & & & & \\
\hline & 367 & 2.99 & 327 & 2.66 \\
\hline & 193 & 1.57 & 184 & 1.50 \\
\hline
\end{tabular}

From Albin et al., 1990
Low doses of ketamine in humans do not necessarily alter perception in a negative way. Foster et al. (1991) gave an i.v. infusion of three different subanesthetic doses of ketamine $(0.05,0.1$ and $0.2 \mathrm{mg} / \mathrm{kg} / \mathrm{h})$ to six patients with Alzheimer's disease. The patients showed no drowsiness and their reaction times and digit span were unaffected by any of the doses of ketamine used. Surprisingly, there was a dose-related improvement in finger tapping speed, as well as improvement in the Buschke Selective Reminding Test recall and long-term retrieval scores. Low doses of ketamine were well tolerated in these patients. Since NMDA receptors are involved in brain function, including arousal and memory, this study requires further research and explanation because one would have predicted exactly the opposite effects even with the small doses of ketamine used.

\section{Dizocilpine (MK-801)}

When MK-801 was first described by Clineschmidt $e t$ al. $(1982 a-c)$, it was viewed as a potent anticonvulsant, central sympathomimetic with apparent anxiolytic properties. Shortly thereafter, a young graduate student at the University of Michigan informed this author that MK-801 had potent phencyclidine-like effects in animals. Rather than having an open mind to this possibility, this author informed the young person that he was in error because the chemical structure of MK-801 was so different from phencyclidine. It is a lesson this old professor will never forget, for he did not observe the animals given MK-801 and instead relied on his 


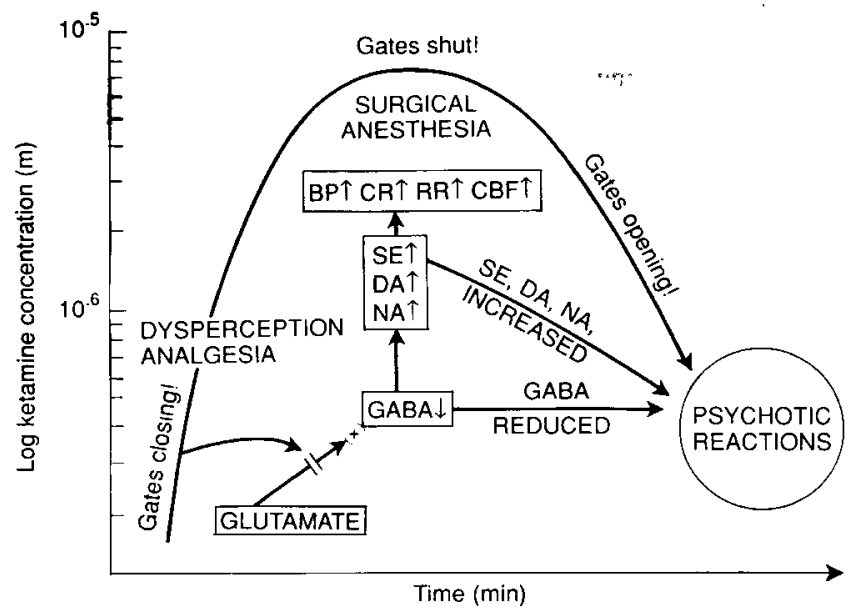

Figure 1 Effects of ketamine on the gates of perception. A model for the action of $S$-ketamine in humans. (A similar model for $R$-ketamine would have to include putative sigma receptor-mediated effects.) On increasing concentrations, $S$ ketamine blocks an increasing number of NMDA receptoroperated channels. 'The gates of perception' are gradually closed, resulting in analgesia and dysperceptions. Ketamine also inhibits NMDA receptor-mediated feedback to inhibitory centers (GABAergic) and the decreased inhibitory activity leads to release of monoamines. Further increase of ketamine causes the characteristic 'dissociative' anesthesia during which muscle tone and reflexes are maintained and circulation and respiration are enhanced. According to this model, excitation, dreams and hallucinations during wakening from ketamine anesthesia are due to increased monoamine activity combined with decreased GABAergic tone. The psychopharmacological effects during subanesthetic (pre-anesthetic) concentrations may mimic some of the 'negative symptoms' in mental disease, whereas the psychopharmacological effects during wakening ('emergence phenomena') also include 'positive' (haloperidol-sensitive) symptoms. Benzodiazepines counteract both the increase in monoamines during the period of anesthesia and the psychotomimetic emergence phenomena. (From Øye et al., 1991)

'knowledge'. How wrong one can be when one does not observe a phenomenon first hand.

Iversen et al. (1988) summarized some of the pharmacology and neuroprotective effects of MK-801 as an NMDA antagonist as described by Kemp, Priestley and Woodruff (1986) and Wong et al. (1986). Unfortunately, MK-801 has not been well studied in humans. During its early clinical trials as an anticonvulsant, Troupin et al. (1986) used small doses of MK-801 as a supplemental therapy in drug-resistant epileptics. Initially the epileptic patients improved, but surprisingly showed rapid tolerance to MK-801's therapeutic effect. Larger doses of MK- 801 produced significant mental side effects which were sufficient cause to discontinue further study. Reimherr, Wood and Wender (1986) conducted an open trial of MK-801 in a small group of residual attention deficit disordered adults. Some of the females had an improvement in temper, emotional reactivity, mood and concentration but this was not as clear in the males. A few of the patients liked the 'beneficial' effects of MK-801. The mental and dysphoric effects of larger doses of MK-801 have not been adequately studied, especially when given parenterally. Therefore, our knowledge of the effects of dizocilpine on human awareness is very incomplete. Stimulus discriminative and other studies in animals indicate that the behavioral effects of this agent are phencyclidine like (Koek and Woods, 1988a,b).

\section{$( \pm) N$-Allylnormetazocine [NANM, $( \pm)$ SKF-10,047]}

A remarkable literature has accumulated since Martin $e t$ al. (1976) described the canine delirium induced with $( \pm)$ SKF-10,047. They suggested that $( \pm)$ SKF-10,047 is a ligand for a sigma 'opioid' receptor. We now know that (-)SKF-10,047 has opioid properties and that in low concentrations $(+)$ SKF-10,047 is a ligand for a nonopioid sigma receptor and in very high concentrations a ligand for the PCP site in the ion channel of the NMDA receptor. Musacchio (1990) reviewed the relationship between the psychotomimetic effects of opiates and the sigma receptor. He concluded that the dysphoric and psychotomimetic effects of opiates reside with the $(-)$ and not the $(+)$ enantiomers. Naloxone does not antagonize the effects of phencyclidine and $( \pm)$ SKF-10,047 in dogs (Vaupel, 1983). Vaupel has also shown that (+)SKF-10,047 produces typical phencyclidine-like effects in dogs, while (-)SKF-10,047 is less potent. The term sigma receptor has taken on a new meaning. A very large literature exists on this subject (see symposia volumes by Domino and Kamenka, 1988; Kamenka and Domino, 1992).

Keats and Telford (1964) found that $( \pm$ )SKF-10,047 is dysphoric in humans. Whether $(+)$ SKF-10,047 is more dysphoric than (-)SKF-10,047 in humans is unknown. The effects of both agents given separately on human awareness have yet to be determined. In animal behavioral experiments (+)SKF-10,047 is phencyclidinelike (Brady, Balster and May, 1982; Koek and Woods, $1988 \mathrm{a}, \mathrm{b}$ ) and is a NMDA antagonist (Largent, Gundlach and Schneider, 1986).

\section{Etoxadrol, dioxadrol and its enantiomers dexoxadrol and levoxadrol}

Both etoxadrol and dioxadrol are structurally different from phencyclidine, yet they share similar pharmacological properties in animals and man. In humans, 
etoxadrol produces a dissociative anesthetic state characterized by analgesia and amnesia, with emergence reactions (Frederickson, Longnecker and Allen, 1976; Wilson et al., 1970, 1973). Dioxadrol, a related compound, has a pharmacology similar to etoxadrol. The $(+)$ enantiomer of dioxadrol is dexoxadrol and the ( - ) enantiomer is levoxadrol. Jasinski, Martin and Sappira (1968), Lasagna and Pearson (1965) and Simopoulos et al. (1970) reported analgesic and psychotomimetic effects with dexoxadrol in humans that are similar to those reported with phencyclidine. Hampton et al. (1982) have shown dexoxadrol to be a potent displacer of $\left[{ }^{3} \mathrm{H}\right] \mathrm{PCP}$ binding in vitro in contrast to levoxadrol. Berry, Anis and Lodge (1984) have shown that both etoxadrol and dexoxadrol selectively antagonize NMDA relative to quisqualate and kainate in rat spinal cord neurons in contrast to levoxadrol. Hence, it is clear that still another class of NMDA antagonists alter human awareness.

\section{Future studies}

To date, almost all of the published studies in humans have been with the non-competitive antagonists of NMDA receptors of glutamic acid. It is clear that such agents cause marked dissociation of human awareness, producing in small to moderate doses altered perceptions and mood suggestive of some of the signs and symptoms of both schizophrenia and dementia. As more drugs are developed that are safe to test in man and that act at different sites in the NMDA receptor complex, it will be possible to obtain a better appreciation of the role of one aspect of glutamic acid function on human awareness. Many very interesting compounds have already been developed that act at different sites in the NMDA complex in vivo and in vitro in animals. Future studies of the human psychopharmacology of such compounds will be very interesting and potentially of therapeutic importance.

\section{Acknowledgement}

Supported in part by NIDA grant DA-01311.

\section{Address for correspondence}

\author{
E. F. Domino \\ Department of Pharmacology \\ University of Michigan \\ Ann Arbor \\ MI 48109-0626 \\ USA
}

\section{References}

Albin M S, Bunegin L, Garcia C (1990) Ketamine and postanesthetic emergence reactions. In Domino E F (ed.), Status of ketamine in anesthesiology. NPP Books, Ann Arbor, pp. 17-25

Berry SC, Anis N A, Lodge D (1984) The effect of the dioxolanes on amino acid induced excitation in the mammalian spinal cord. Brain Res 307: 85-90

Brady K T, Balster R L, May EL (1982) Stereoisomers of $\mathrm{N}$-allylnormetazocine: Phencyclidine-like behavioral effects in squirrel monkeys and rats. Science 215: 178-180

Burns R S, Lerner S E (1981) The effects of phencyclidine in man: A review. In Domino EF (ed.), PCF (phencyclidine): historical and current perspectives. NPP Books, Ann Arbor, pp. 449-470

Carlsson M, Carlsson A (1990) Interactions between glutamatergic and monoaminergic systems within the basal ganglia-implications for schizophrenia and Parkinson's disease. Trends Neuropsychol 13: 272-276

Chen G (1981) The neuropharmacology of phencyclidine. In Domino E F (ed.), PCP (phencyclidine): historical and current perspectives. NPP Books, Ann Arbor, pp. 9-16

Clineschmidt BV, Martin GE, Bunting PR (1982a) Anticonvulsant activity of (+)-5-methyl-10,11-dihydro. 5H-dibenzo [a,d] cyclohepten-5,10-amine (MK-801), a substance with potent anticonvulsant, central sympathomimetic, and apparent anxiolytic properties. Drug Dev Res 2: 123-134

Clineschmidt B V, Martin G E, Bunting P R, Papp N L (1982b) Central sympathomimetic activity of (+)-5. methyl-10,11-dihydro-5H-dibenzo [a,d ] cyclohepten-5,10. amine (MK-801), a substance with potent anticonvulsant, central sympathomimetic, and apparent anxiolytic properties. Drug Dev Res 2: 135-145

Clineschmidt B V, Williams M, Witoslawski J J, Bunting P R, Risley E A, Totaro J A (1982c) Restoration of shock. suppressed behavior by treatment with (+)-5-methyl-10,11. dihydro-5H-dibenzo [a,d] cyclohepten-5,10-amine (MK-801), a substance with potent anticonvulsant, central sympathomimetic, and apparent anxiolytic properties. Drug Dev Res 2: 147-163

Cohen B D, Rosenbaum G, Luby E D, Gottlieb J S, Yelen D (1959) Comparison of Sernyl with other drugs. I. Attention, motor function and proprioception. Arch Gen Psychiatr 1: 651-656

Corssen G (1990) Historical aspects of ketamine-first clinical experience. In Domino E F (ed.), Status of ketamine in anesthesiology. NPP Books, Ann Arbor, pp. 1-5

Corssen G, Domino E F (1966) Dissociative anesthesia: Further pharmacologic studies and first clinical experience with the phencyclidine derivative CI-581. Anesth Analg 45: 29-40

Domino E F, Chodoff P, Corssen G (1965) Pharmacologic effects of CI-581, a new dissociative anesthetic in man. Clin Pharmacol Ther 6: 279-291

Domino EF, Luby ED (1981) Abnormal mental states induced by phencyclidine as a model of schizophrenia. In Domino E F (ed.), PCP (phencyclidine): historical and current perspectives. NPP Books, Ann Arbor, pp. 401-418

Domino E F, Kamenka J-M, eds (1988) Sigma and phencyclidine-like compounds as molecular probes in biology. NPP Books, Ann Arbor 
Dundee J W (1990a) Early British experience with ketamine. In Domino E F (ed.), Status of ketamine in anesthesiology. NPP Books, Ann Arbor, pp. 7-10

Dundee J W (1990b) The taming of ketamine. In Domino E F (ed.), Status of ketamine in anesthesiology. NPP Books, Ann Arbor, pp. 11-16

Fauman M A, Fauman B J (1981) Chronic phencyclidine (PCP) abuse: A psychiatric perspective. In Domino E F (ed.), PCP (phencyclidine): historical and current perspectives. NPP Books, Ann Arbor, pp. 419-436

Foster N L, Giordani B, Mellow A, Aronson S, Berent S (1991) Memory effects of low-dose ketamine in Alzheimer's disease. Neurology 41: 214

Frederickson E L, Longnecker D E, Allen G W (1976) Clinical investigation of a new intravenous anestheticetoxadrol hydrochloride (Cl-1848:U-37862A). Anesth Analg Curr Res 55: 335-339

Greifenstein F E, DeVault M, Yoshitake J, Gajewski J E (1958) A study of 1-arylcyclohexylamine for anesthesia. Anesth Analg 37: 283-294

Hampton R Y, Medzihradsky F, Woods J H, Dahlstrom P J (1982) Stereospecific binding of ${ }^{3} \mathrm{H}$-phencyclidine in brain membranes. Life Sci 30: 2147-2154

Iversen L L, Woodruff G N, Kemp J A, Foster A C, Gill R, Wong E H F (1988) Pharmacology and neuroprotective effects of the NMDA antagonist MK-801. In Domino E F, J-M Kamenka (eds), Sigma and phencyclidine-like compounds as molecular probes in biology. NPP Books, Ann Arbor, pp. 757-766

Javitt DC, Zukin SR (1991) Recent advances in the phencyclidine model of schizophrenia. Am J Psychiatr 148: 1301-1308

Jasinski D R, Martin W R, Sappira J D (1968) Progress report on the dependence-reducing properties of GPA-1657, profadol hydrochloride (CI-572), propiram fumarate (BAY-4503) and dexoxadrol. Reported to the 30th Meeting, Committee on Problems of Drug Dependence, National Research Council, Indianapolis IN

Johnstone M, Evans V, Baigel J R (1959) Sernyl (CI-395) in clinical anesthesia. Br J Anaesth 31: 433-439

Kamenka J-M, Domino E F, eds (1992) Multiple sigma and PCP ligands: mechanisms for neuromodulation and neuroprotection? NPP Books, Ann Arbor

Keats A S, Telford J (1964) Narcotic antagonists as analgesics. In Gould R F (ed.), Clinical aspects, series 45: molecular modification in drug design, advances in chemistry. American Chemical Society, Washington, pp. 170-176

Kemp J A, Priestley T, Woodruff G N (1986) MK-801, a novel orally-active anticonvulsant, is a potent noncompetitive N-methyl-D-aspartate receptor antagonist. Br J Pharmacol Proc Suppl 89: 535P

Koek W, Woods J H (1988a) Assessing directly observable behavioral effects of phencyclidine (PCP)-like drugs in pigeons, in rats, and in rhesus monkeys. In Domino E F, Kamenka J-M (eds), Sigma and phencyclidine-like compounds as molecular probes in biology. NPP Books, Ann Arbor, pp. 493-509

Koek W, Woods JH (1988b) Correlations between phencyclidine-like activity and N-methyl-D-aspartate antagonism: Behavioral effects. In Domino E F, Kamenka J-M (eds), Sigma and phencyclidine-like compounds as molecular probes in biology. NPP Books, Ann Arbor, pp. 357-372

Largent BL, Gundlach AL, Schneider SH (1986) Pharmacological and autoradiographical discrimination of sigma and phencyclidine receptor binding sites in brain with $(+)\left[{ }^{3} \mathrm{H}\right]$ SKF-10,047, (+) $\left[{ }^{3} \mathrm{H}\right] 3-\mathrm{PPP}$, and $\left[{ }^{3} \mathrm{H}\right] \mathrm{TCP}$. $J$ Pharmacol Exp Ther 238: 739-748

Lasagna L, Pearson J W (1965) Analgesic and psychotomimetic properties of dexoxadrol. Proc Soc Exp Biol Med 118: $352-354$

Lear E, Suntay R, Pallin IN, Chiron A E (1959) Cyclohexamine (CI-400): A new intravenous agent. Anesthesiology 20: 330-335

Lodge D, Anis N A, Berry SC, Burton N R (1983) Arylcyclohexylamines selectively reduce excitation of mammalian neurones by aspartate-like amino acids. In Kamenka J-M, Domino E F, Geneste P (eds), Phencyclydine and related arylcylohexylamines: present and future applications. NPP Books, Ann Arbor, pp. 595-616

Luby E D (1981) Phencyclidine revisited. In Domino E F (ed.), PCP (phencyclidine): historical and current perspectives. NPP Books, Ann Arbor, pp. 25-30

Luby E D, Cohen B D, Rosenbaum G, Gottlieb J S, Kelley $R$ (1959) Study of a new schizophrenomimetic drugSernyl. Arch Neurol Psychiatr 81: 363-369

Luby E D, Gottlieb J S, Cohen B D, Rosenbaum G, Domino E F (1962) Model psychoses and schizophrenia. Am J Psychiatr 119: 61-67

Maddox VH (1981) The historical development of phencyclidine. In Domino EF (ed.) PCP (phencyclidine): historical and current perspectives. NPP Books, Ann Arbor, pp. 1-8

Martin W R, Eades C G, Thompson J A, Huppler R E, Gilbert P E (1976) The effects of morphine and nalorphinelike drugs in the non-dependent and morphine-dependent chronic spinal dog. J Pharmacol Exp Ther 197: 517-532

McCarthy DA (1981) History of the development of cataleptoid anesthetics of the phencyclidine type. In Domino EF (ed.), PCP (phencyclidine): historical and current perspectives. NPP Books, Ann Arbor, pp. 17-23

Meyer J S, Greifenstein F, DeVault M (1959) A new drug causing symptoms of sensory deprivation: Neurological, electroencephalographic and pharmacologic effects of Sernyl. J Nerve Ment Dis 129: 54-61

Musacchio JM (1990) The psychotomimetic effects of opiates and the $\sigma$ receptor. Neuropsychopharmacology 3 : 191-200

Øye I, Hustveit O, Maurset A, Ratti Mobert E, Paulsen O, Skoglund L A (1991) The chiral forms of ketamine as probes for NMDA receptor functions in human. In Kameyama T, Nabeshima T, Domino E F (eds), NMDA receptor related agents: biochemistry, pharmacology and behavior. NPP Books, Ann Arbor, pp. 381-390

Reimherr F W, Wood D R, Wender P H (1986) The use of MK-801, a novel sympathomimetic, in adults with attention deficit disorder, residual type. Psychopharmacol Bull 22: 237-242

Scholler K L, Thies H, Wiemers K (1960) Die Allgemeinanaesthesie mit Cyclohexylaminodrivaten, klinische Beobachtungen und elektrencephalographische Untersuchungen (General anesthesia with cyclohexylamine derivatives, clinical observations and electroencephalographic studies). Der Anaesthesist 9: 163-169 
Simopoulos A M, Pinto A, Babikow PW, Curland A, Savage C (1970) Psychotomimetic properties and therapeutic potentials of dexoxadrol in convalescing alcoholics. Disease Nerv Syst 31: 203-207

Troupin A S, Mendius J R, Cheng F, Risinger M W (1986) MK-801. In Meldrum B S, Porter R J (eds), New anticonvulsant drugs. John Libbey, London, pp. 191-201

Vaupel D B (1983) Naltrexone fails to antagonize the $\sigma$ effects of PCP and SKF-10,047 in the dog. Eur $J$ Pharmacol 92: 269-274

Wilson R D, Traber D L, Barratt E, Creson D, Schmitt R, Allen C R (1970) Evaluation of CL-1848C: A new dissociative anesthetic in normal human volunteers. Anesth Analg Curr Res 49: 236-241

Wilson R D, Allen C R, Creson D, Schmitt R, Barratt E, Traber DL (1973) Operant behavior and neurophysiological observations of normal human volunteers receiving CL-1848C, a new dissociative anesthetic. Tex Rep Biol Med 31: 239-248

Wong E H F, Kemp J A, Priestley T, Night A R, Woodruff $\mathrm{G} \mathrm{N}$, Iversen L L (1986) The anticonvulsant MK-801 is a potent $\mathrm{N}$-methyl-D-aspartate antagonist. Proc Natl Acad Sci USA 83: 7104-7108 